\title{
TINGKAT KELANGSUNGAN HIDUP DAN RASIO KONVERSI PAKAN PADA BUDIDAYA IKAN GURAMI (Osphronemus goramy LAC.) DENGAN SISTEM BIOFLOK DAN PEMBERIAN PAKAN KADAR PROTEIN YANG BERBEDA THE SURVIVAL RATE AND FEED CONVERSION RATIO ON THE CULTURE OF GIANT GOURAMY (Osphronemus goramy LAC.) WITH BIOFLOC SYSTEM AND FEEDING OF DIFFERENT PROTEIN LEVELS
}

\author{
Retno Wijayanti ${ }^{a}$, Muarif ${ }^{\text {b }}$, Dudi Lesmana ${ }^{b}$ \\ ${ }^{a}$ PT Pahala Bahari Nusantara \\ ${ }^{b}$ Staf Pengajar Program Studi Akuakultur, Fakultas Pertanian, Universitas Djuanda Bogor \\ Email : retnowijayanti639@gmail.com
}

\begin{abstract}
This research was carried out on March to August, 2018, and the experiment on April to June, 2018 at the Fishery Laboratory, Djuanda University Bogor. The objective of research is to know and analyze the survival rate and feed conversion ratio of Giant Gouramy that cultured on biofloc media and different protein levels. The experimental design that used is completely randomized design with 2 treatments and 6 replications. The treatments are treatment $\mathrm{A}$ (feeding of protein level of $17 \%+$ mollase addition with $\mathrm{C}, / \mathrm{N}$ ratio 12 ) and treatment $\mathrm{B}$ (feeding of protein level of $30 \%$ without mollase) Fish that used is Giant Gouramy fry with length 5-7 cm that maintained cylinder container of diameter $1 \mathrm{~m}$ and height $1 \mathrm{~m}$. The results of research that the artificial feeding of protein level of $17 \%+$ mollase addition with $\mathrm{C} / \mathrm{N}$ ratio 12 gives the survival rate which is better, but the feed conversion ratio is bad. The average of the highest survival rate of Giant Gouramy is $89 \%$ (treatment A) and the low feed conversion ratio is 1.6 (treatment $\mathrm{B}$ ). Water quality during the research are temperature of $23,6-30,0{ }^{\circ} \mathrm{C}$, dissolved oxygen of 6.4- $8.8 \mathrm{mg} / \mathrm{l}$ and $\mathrm{pH}$ of 6,3-8,8.
\end{abstract}

Key words: Giant Gouramy, biofloc, feed conversion ratio, protein level.

\begin{abstract}
ABSTRAK
Penelitian ini dilaksanakan pada bulan Maret-Agustus 2018, dan tahap percobaannnya dilaksanakan pada bulan April-Juni 2018 di Laboratorium Perikanan Universitas Djuanda Bogor. Tujuan dari penelitian ini adalah untuk menelaah tingkat kelangsungan hidup ikan gurami dan rasio konversi pakannya, pada media poemeliharaan bioflok dengan pemberian protein pakan yang berbeda. Rancangan penelitian ini berupa rancangan acak lengkap dengan dua perlakuan dan enam kali ulangan. Perlakuan yang diuji yaitu A (pemberian pakan berprotein $17 \%$ dengan penambahan molase $\mathrm{C} / \mathrm{N}$ ratio 12 ) dan $\mathrm{B}$ (Pemberian pakan berprotein $30 \%$ tanpa molase). Ikan yang digunakan adalah benih ikan Gurami dengan panjang 5-7 cm yang dipelihara pada wadah bak silinder berdiameter 1 meter dan tinggi 1 meter. Hasil penelitian menunjukan bahwa pemberian pakan buatan dengan kadar protein $17 \%$ dengan penambahan molase $\mathrm{C} / \mathrm{N}$ ratio 12 menghasilkan kelangsungan hidup yang lebih baik, akan tetapi rasio konversi pakan yang dihasilkan tinggi (kurang baik). Rata-rata kelangsungan hidup ikan gurami tertinggi sebesar $89 \%$ (perlakuan A) dan rasio konversi pakan terendah sebesar 1,6
\end{abstract}


(perlakuan B). Hasil pengukuran kualitas air untuk suhu berkisar $23,6-30{ }^{\circ} \mathrm{C}$, pH 6,4 - 8,8 dan DO $6,3-8,8$.

Kata Kunci: Ikan Gurami, bioflok, pakan

Retno Wijayanti, Muarif, Dudi Lesmana. 2019. Tingkat Kelangsungan Hidup dan Rasio Konversi Pakan pada Budidaya Ikan Gurami (Osphronemus goramy LAC.) dengan Sistem Bioflok dan Pemberian Pakan Kadar Protein yang Berbeda. Jurnal Mina Sains 5(1): 42 - 49.

\section{PENDAHULUAN Latar Belakang}

Ikan Gurami adalah ikan asli perairan Indonesia yang memiliki keunggulan antara lain tinggi kandungan protein, rendah koletrol, dan mudah dicerna sehingga banyak digemari oleh masyarakat (Zakaria 2008). Menurut Dirjen Perikanan Budidaya (2014; 2016) produksi ikan Gurami tergolong masih rendah dibanding dengan produksi ikan air tawar lainnya. Lambatnya pertumbuhan dan rendahnya tingkat kelangsungan hidup menjadi faktor utama penyebab rendahnya produksi ikan Gurami. Harga jual ikan ini tinggi sehingga masih tetap dibudidayakan oleh para pembudidaya ikan, walaupun pemeliharaannya membutuhkan waktu yang lama dan biaya produksi yang tergolong tinggi (Ohoiulun 2003).

Upaya peningkatan produksi dilakukan melalui budidaya ikan secara intensif (Emerenciano et al. 2013), kepadatan tinggi (Sulistyo et al. 2016), kualitas pakan yang baik, dan pengelolaan kualitas air yang baik (Diatin 2016). Pada budidaya intensif, sumber makanan bagi biota yang dibudidayakan adalah pakan buatan (komersil) (Ekasari 2009).

Pakan yang diberikan tidak semua dapat dikonsumsi. Sekitar $64 \%$ pakan dimanfaatkan menjadi biomassa ikan dan ikan hanya mampu meretensi protein pada pakan sekitar $20-25 \%$, sedangkan $75 \%$ tidak dimanfaatkan dan tetap menjadi buangan limbah di perairan (media budidaya) (Crab et al. 2012). Limbah pakan di perairan dapat berupa nitrogen anorganik yakni amonia dan nitrit yang bersifat toksik pada ikan (Schryver et al. 2008).

Teknologi bioflok merupakan salah satu solusi untuk memperbaiki permasalahan pada budidaya intensif. Menurut Crab et al. (2012) teknologi bioflok bertujuan untuk mempebaiki kualitas air (menurunkan konsentrasi amoniak) dengan teknik menambahkan unsur C (karbon) ke dalam media budidaya yang dapat memicu pertumbuhan bakteri heterotrof. Pada kondisi rasio karbon dan nitrogen yang seimbang dalam perairan, amonium selain nitrogen akan diubah menjadi biomassa bakteri melalui produksi protein mikroba (Avnimelech 1999). Serapan nitrogen dengan penambahan C oleh bakteri dapat menurunkan kadar ammonium lebih cepat daripada proses nitrifikasi (Hargreaves 2013).

Penelitian mengenai bioflok untuk ikan Gurami sebelumnya sudah dilakukan, dimana $\mathrm{C} / \mathrm{N}$ ratio 12 memberikan rasio konversi pakan dan kelangsungan yang tinggi pada perlakuan penambahan molase (Rosmawati dan Muarif 2017), dengan kandungan protein pakan $30 \%$.

Pada penelitian ini pemeliharaan ikan Gurami dilakukan dengan mengurangi kadar protein yang digunakan pada penelitian sebelumnya dan kadar protein yang digunakan disesuaikan dengan yang beredar di pasaran yaitu kadar protein $17 \%$ dengan dilakukan penambahan molase $\mathrm{C} / \mathrm{N}$ ratio 12 yang disarankan pada penelitian Rosmawati dan Muarif (2017). Flok yang tumbuh pada penelitian ini diharapkan dapat menjadi sumber protein pakan, sehingga pakan lebih efisien dan dapat 
menghemat biaya pakan serta mengurangi amonia di perairan.

\section{Tujuan}

Penelitian ini bertujuan mengetahui tingkat kelangsungan hidup dan rasio konversi pakan ikan Gurami yang dipelihara pada media bioflok dengan kadar protein pakan yang berbeda.

\section{BAHAN DAN METODE Waktu dan Tempat Penelitian}

Penelitian berlangsung selama 6 bulan (Maret - Agustus 2018), berlokasi di Laboratorium Perikanan, Fakultas Pertanian, Universitas Djuanda Bogor, Ciawi, Kabupaten Bogor.

\section{Alat dan Bahan}

Peralatan yang digunakan dalam penelitian ini adalah wadah pemeliharaan berupa bak terpal silinder sebanyak 12 unit dengan diameter $1 \mathrm{~m}$ dan tinggi $1 \mathrm{~m}$, bak fiber ukuran $2,5 \times 1,4 \times 0,6 \mathrm{~m}^{3}$ sebanyak 1 unit, blower/pompa aerasi 2 unit, selang aerasi, batu aerasi, selang air 3/4, pompa air celup, timbangan digital, penggaris, $\mathrm{pH}$ meter untuk mengukur $\mathrm{pH}$ air serta DO meter untuk mengukur DO dan suhu air. Alat-alat tambahan seperti baskom, seser, ember dan waring untuk mengambil ikan.

Penelitian ini menggunakan bahan berupa ikan gurame ukuran $5-7 \mathrm{~cm}$ sebanyak 50 ekor/wadah, yang dipelihara selama 45 hari. Bahan lain yang digunakan adalah pakan buatan ( protein $17 \%$ dan $30 \%$ ), molase, dan EM-4.

\section{Rancangan Percobaan}

Penelitian ini menggunakan Rancangan Acak Lengkap (RAL) yang terdiri atas 2 perlakuan (perlakuan A (Pemberian pakan dengan kadar protein $17 \%$ dan penambahan molase $\mathrm{C} / \mathrm{N}$ ratio 12 ) serta perlakuan B (Pemberian pakan dengan kadar protein $30 \%$ tanpa molase) dan 6 kali ulangan. Model persamaan linier menurut
Steel dan Torrie (1985) adalah sebagai berikut :

$$
\begin{aligned}
& \boldsymbol{Y}_{\boldsymbol{i j}}=\boldsymbol{\mu}+\boldsymbol{\sigma}_{\boldsymbol{i}}+\boldsymbol{\varepsilon}_{\mathbf{i j}} \\
& Y_{i j}= \text { Data hasil pengamatan pada } \\
& \text { perlakuan ke-i dan ulangan ke- } \mathrm{j}
\end{aligned}
$$

\section{Prosedur Percobaan Pemeliharaan Ikan}

Wadah budidaya berupa bak terpal berbentuk silinder berdiameter satu meter dan tinggi satu meter. Wadah diisi air dengan ketinggian $70 \mathrm{~cm}$ dan diisi ikan sebanyak 50 ekor/wadah. Ikan dipelihara selama 45 hari. Frekuensi pemberian pakan dilakukan sebanyak 2 kali sehari yaitu pada jam 08.00 dan 16.00 WIB secara at satiation. Penambahan molase hanya dilakukan pada wadah pemeliharaan ikan yang diberi pakan $17 \%$. Pemberian molase dilakukan satu kali sehari satu jam setelah pemberian pakan terakhir. Selama proses percobaan berlangsung tidak dilakukan penggantian air, tetapi dilakukan penambahan air yang hilang akibat penguapan.

\section{Penambahan Karbon (Molase)}

Sumber karbon organik untuk meningkatkan rasio $\mathrm{C} / \mathrm{N}$ yaitu molase, tepung terigu, tepung tapioka, dedak, dan onggok (Azhar 2013; Aji et al. 2014). Sumber karbon pada penelitian ini adalah molase. Molase mengandung 58,9\% dan NTotal 0,9\% (Kusuma et al. 2017) Penambahan karbon dilakukan setiap hari (1 jam setelah pemberian pakan terakhir) dengan estimasi $\mathrm{C} / \mathrm{N}$ rasio 12 . Jumlah karbon yang ditambahkan untuk mendukung proses pembentukan flok oleh bakteri heterotrof menggunakan rumus (Schryver et al. 2008). 


\section{Parameter yang Diamati Tingkat Kelangsungan Hidup}

Tingkat Kelangsungan hidup dihitung menggunakan rumus (Effendie 1997):

Keterangan :

$$
\mathrm{Sr}=\frac{\mathrm{Nt}}{\mathrm{No}} \times 100 \%
$$

$\mathrm{Sr}=$ Tingkat Kelangsungan Hidup (\%)

$\mathrm{Nt}=$ Populasi ikan akhir pemeliharaan (ekor)

No $=$ Populasi ikan awal pemeliharaan (ekor)

\section{Rasio Konversi Pakan}

$\begin{array}{ccc}\text { Rasio } & \text { konversi pakan } & \text { selama } \\ \text { pemeliharaan } & \text { dihitung } & \text { dengan } \\ \text { menggunakan } & \text { rumus Zonneveld } \text { et al. }\end{array}$ (1991):

Keterangan :

$$
\boldsymbol{R K P}=\frac{\boldsymbol{F}}{\boldsymbol{B}_{t}+\boldsymbol{B}_{m}-\boldsymbol{B}_{\boldsymbol{o}}}
$$

RKP $=$ Rasio konversi pakan

$\mathrm{B}_{\mathrm{t}} \quad=$ Biomassa ikan akhir pemeliharaan

$\mathrm{B}_{\mathrm{O}}=$ Biomassa ikan awal pemeliharaan (gram)

$\mathrm{B}_{\mathrm{m}}=$ Biomassa ikan yang mati selama penelitian (gram)

$\mathrm{F}=$ Jumlah Pakan (gram)

\section{Parameter Kualitas air}

Parameter kualitas air yang di ukur dalam penelitian ini dapat dilihat pada Tabel 1.

Tabel 1 Alat dan Metode untuk Mengukur Kualitas Air

\begin{tabular}{ccc}
\hline Parameter & Satuan & $\begin{array}{c}\text { Metode/ } \\
\text { Alat }\end{array}$ \\
\hline Suhu & ${ }^{\circ} \mathrm{C}$ & Termometer \\
pH & - & pH-meter \\
DO & $\mathrm{mg} / \mathrm{L}$ & DO-meter \\
\hline
\end{tabular}

\section{Analisis Data}

Data yang diperoleh kemudian dianalisis menggunakan analisis ragam (ANOVA) program MS.Excel 2016 dan SPSS 21.0 pada taraf kepercayaan $95 \%$ untuk melihat pengaruh dari perlakuan yang diberikan.

\section{HASIL DAN PEMBAHASAN Kelangsungan Hidup Ikan Gurami}

Kelangsungan hidup ikan Gurami yang dipelihara selama 45 hari memiliki kisaran 30 - 98\%. Pada media bioflok (perlakuan A) kelangsungan hidup ikan Gurami lebih tinggi yaitu $80-98 \%$ dengan rataan $89 \%$ sedangkan pada perlakuan kedua (perlakuan B) tanpa bioflok kelangsungan hidup ikan Gurami diperoleh hasil antara $30-46 \%$. Hasil analisis sidik ragam (ANOVA) pada selang kepercayaan 95\% diperoleh data bahwa perlakuan $\mathrm{A}$ (pakan buatan kadar protein $17 \%$ ditambah molase $\mathrm{C} / \mathrm{N}$ ratio 12 ) berbeda nyata (Tabel 2).

Tingkat kelangsungan hidup ikan Gurami pada perlakuan A yang tinggi, diduga molase yang ditambahkan dapat menumbuhkan bakteri menguntungkan pada media budidaya sehingga dapat memperbaiki kualitas air dan menekan pertumbuhan bakteri pathogen di perairan. Sesuai dengan penelitian Azhar (2013) dan Apriani (2015) media bioflok (penambahan karbon) memberikan tingkat kelangsungan hidup udang yang lebih tinggi. Selain itu bakteri yang tumbuh pada media bioflok dengan sumber karbon molase mampu menekan pertumbuhan bakteri pathogen. (Apriani 2015; Usman 2011).

Tabel 2 Kelangsungan Hidup (\%) Ikan Gurami Selama Penelitian

\begin{tabular}{ccc}
\hline \multirow{2}{*}{ Ulangan } & \multicolumn{2}{c}{ Perlakuan } \\
\cline { 2 - 3 } & $\mathrm{A}$ & $\mathrm{B}$ \\
\hline 1 & 88 & 32 \\
2 & 84 & 46 \\
3 & 80 & 46 \\
4 & 98 & 40 \\
5 & 86 & 46 \\
6 & 98 & 30 \\
\hline Rataan \pm S.D & $89 \pm 7,4^{\mathrm{a}}$ & $40 \pm 7,3^{\mathrm{b}}$ \\
\hline Keterangan: A (pakan buatan kadar protein 17\% \\
\multicolumn{3}{c}{ ditambah molase C/N ratio 12) dan } \\
B (pakan buatan kadar protein 30 \% \\
tanpa molase) \\
Superscript berbeda menunjuk-kan \\
nilai berbeda nyata (P<0,05).
\end{tabular}


Menurut Manurung (2017) jenis bakteri pathogen berkembang pada kondisi kualitas air yang kurang mendukung. Perlakuan B memiliki kandungan nitrogen lebih banyak dan tidak terurai dengan baik walaupun dilakukan proses penyiponan, sehingga tumbuh bakteri pathogen di perairan.

Menurut Putri (2014) penambahan bakteri heterotrof seperti bakteri Bacillus mampu mendekomposisi bahan organik di perairan sehingga memberi kualitas air yang baik. Farzanfar (2006) berpendapat keberadaan Bacillus spp. dapat menurunkan jumlah bakteri patogen di media budidaya.

Menurut Apriani (2015) tingginya tingkat kelangsungan hidup pada perlakuan penambahan karbon dikarenakan dalam media terdapat flok dan bioflok yang tumbuh dapat mengakumulasi komponen poly- $\beta$ hydroxybutirate (PHB) yang memiliki peran dalam mengontrol bakteri pathogen di perairan. Kandungan PHB pada bioflok, apabila dimakan ikan dapat meningkatkan sistem imun ikan (lebih tahan terhadap gangguan pathogen).

\section{Rasio Konversi Pakan (FCR)}

FCR ikan Gurami pada perlakuan A (4,69-6,93 dengan rataan 5,97) lebih besar dibanding perlakuan $\mathrm{B}$ (1,52 - 1,76 dengan rataan 1,63) (Tabel 3). Hasil analisis ragam (ANOVA) menunjukkan antar perlakuan berbeda nyata $(\mathrm{P}<0,05)$.

Tabel 3 Rasio konversi pakan ikan Gurami selama penelitian

\begin{tabular}{ccc}
\hline & \multicolumn{2}{c}{ PERLAKUAN } \\
\cline { 2 - 3 } Ulangan & $\mathrm{A}$ & $\mathrm{B}$ \\
\hline 1 & $*$ & 1,76 \\
2 & 5,79 & 1,52 \\
3 & 5,62 & 1,67 \\
4 & 6,93 & 1,62 \\
5 & 6,82 & 1,54 \\
6 & 4,69 & 1,69 \\
\hline
\end{tabular}

Rataan \pm S.D $\quad 5,97 \pm 0,92^{\mathrm{a}} \quad 1,63 \pm 0,09^{\mathrm{b}}$

Keterangan: A (pakan buatan kadar protein $17 \%$ ditambah molase $\mathrm{C} / \mathrm{N}$ ratio 12 ) dan $\mathrm{B}$ (pakan buatan kadar protein $30 \%$ tanpa molase)
* data tidak digunakan karena merupakan pencilan

Superscript berbeda menunjukan nilai berbeda nyata $(\mathrm{P}<0,05)$.

Rataan rasio konversi pakan pada perlakuan A sebesar 5,97 berarti untuk menghasilkan $1 \mathrm{~kg}$ ikan membutuhkan pakan sebanyak $5,97 \mathrm{~kg}$, tingginya jumlah pakan ini menunjukkan penggunaan pakan tidak efisien. Penelitian Lisah (2004) juga mendapatkan nilai rata-rata FCR ikan Gurami yang tinggi yaitu sebesar 5,00 15,21. Menurut Sutarmat (2006) FCR tinggi mengindikasikan pakan tidak tercerna atau pakan kurang disukai oleh ikan.

Perhitungan energi menunjukkan pada setiap $2.700 \mathrm{kkal} / \mathrm{kg}$ energi pakan yang dikonsumsi ikan perlakuan $\mathrm{A}$, dapat dimanfaatkan untuk pertumbuhan dan metabolisme sehari - hari sebesar $(0,17 \times 2.700 \mathrm{kkal} / \mathrm{kg})$ atau $459 \mathrm{kkal} / \mathrm{kg}$. Energi yang dimanfaatkan ikan perlakuan B energi lebih besar yaitu $(0,30 \times 3.238,94)$ atau $971,4 \mathrm{kkal} / \mathrm{kg}$. Hal ini menunjukkan energi yang dimanfaakan untuk metabolisme dan pertumbuhan ikan pada perlakuan A lebih sedikit dibanding dengan perlakuan B.

Hasil analisis kandungan bobot basah protein flok perlakuan A rendah yaitu berkisar antara $1,55-3,27 \%$, sehingga ikan pada perlakuan A pakan buatan yang dikonsumsi selama penelitian berlangsung lebih banyak yaitu sebesar 3974,2 g, sedangkam perlakuan B sebesar $2973 \mathrm{~g}$. Menurut NRC (1997) jumlah pakan yang terlalu banyak menyebabkan ikan tidak efisien dalam proses pemanfaatannya selain itu energi hasil kecernaan pakan menjadi lebih banyak dikeluarkan apabila pakan yang dikonsumsi lebih banyak sehingga efisiensi pakan rendah.

\section{Kualitas Air}

Hasil pengamatan kualitas air dalam waktu 45 hari berada pada kisaran normal untuk pemeliharaan ikan Gurami. Kualitas air semua perlakuan relatif sama (Tabel 4), meskipun perlakuan A tidak dilakukan pergantian air. Hal ini menunjukkan sistem 
bioflok dapat mengontrol kualitas air, sehingga kualitas air perlakuan A dan perlakuan B relatif sama.

Tabel 4 Kualitas air media pemeliharaan ikan Gurami selama penelitian

\begin{tabular}{ccc}
\hline \multirow{2}{*}{ Parameter } & \multicolumn{2}{c}{ Perlakuan } \\
\cline { 2 - 3 } & $\mathrm{A}(17 \%)$ & $\mathrm{B}(30 \%)$ \\
\hline Suhu $\left({ }^{\circ} \mathrm{C}\right)$ & $23,6-30,0$ & $23,3-29,2$ \\
pH & $6,4-8,8$ & $6,5-8,8$ \\
DO (ppm) & $6,3-8,8$ & $6,3-8,8$ \\
\hline
\end{tabular}

Berdasarkan analisis parameter kualitas air yang diukur setiap hari selama 45 hari pada bak pemeliharaan ikan Gurami, kisaran suhu pada perlakuan A (pakan buatan kadar protein 17\% ditambah molase $\mathrm{C} / \mathrm{N}$ ratio 12 ) yaitu $23,6-30,0{ }^{\circ} \mathrm{C}$ dan pada perlakuan B (pakan buatan kadar protein $30 \%$ tanpa molase) berkisar antara 23,3 - 29, $2^{\circ} \mathrm{C}$, kisaran pada masing-masing perlakuan relatif sama dan tidak adanya perbedaan yang signifikan diantara keduanya. Pada perlakuan A kisaran suhu tersebut tidak menimbukan gangguan dengan dicirikan taraf kelangsungan hidup ikan Gurami yang baik. Pada perlakuan B nilai kisaran suhu yang rendah menyebabkan kehidupan ikan menjadi tidak normal, dicirikan dengan ikan berenang dipermukaan, nafsu makan hilang dan ikan tidak aktif bergerak. Ikan pada perlakuan B diduga terserang bakteri pathogen sehingga kelangsungan hidup ikan Gurami rendah. Menurut Muarif (2016) suhu mempengaruhi proses biologi dan kimia yang berpengaruh terhadap kelangsungan hidup ikan yang dibudidayakan. Sulhi (2007) menyebutkan ikan Gurami sangat rentan terhadap perubahan suhu air yang mendadak.

Kisaran $\mathrm{pH}$ yang didapat selama penelitian berkisar antara perlakuan A (yaitu 6,4 - 8,8 dan perlakuan B 6,5 - 8,8, kondisi media dengan $\mathrm{pH}$ tersebut berada dalam kisaran yang optimum. Menurut Boyd (1979) kisaran optimum $\mathrm{pH}$ untuk menjamin kehidupan ikan yaitu 6,5 - 9,0.

Konsentrasi DO (oksigen terlarut) perlakuan A sebesar 6,3 - 8,8 dan perlakuan
B sebesar 6,3 - 8,8. Kisaran DO pada setiap perlakuan cenderung stabil dan masih berada dalam kisaran optimal. Menurut Boyd (1979) kisaran oksigen yang baik bagi kehidupan ikan adalah diatas 5 ppm. Sesuai dengan pendapat Schryver et al. (2008) bahwa DO dapat mempengaruhi pembentukan flok. Nilai oksigen diatas 5 ppm pada sistem bioflok lebih baik dalam mengurangi volume pengendapan bahan organik, dibuktikan dengan proses nitrifikasi berjalan dengan baik (Usman 2011).

\section{KESIMPULAN DAN SARAN Kesimpulan}

Perlakuan A (pakan buatan kadar protein $17 \%$ ditambah molase $\mathrm{C} / \mathrm{N}$ ratio 12 ) memberikan pengaruh terbaik pada kelangsungan hidup ikan Gurami, sedangkan perlakuan B (pakan buatan kadar protein $30 \%$ tanpa molase) memberikan pengaruh terbaik pada rasio konversi pakan. Pemberian molase $(\mathrm{C} / \mathrm{N}$ rasio 12) pada perlakuan A mampu memberikan kualitas air yang baik bagi media budidaya ikan Gurami.

\section{Saran}

Berdasarkan hasil penelitian yang telah dilakukan disarankan perlu adanya penelitian lanjutan mengenai:

1. Jenis dan jumlah bakteri yang terdapat pada pencernaan ikan Gurami

2. Pemberian kadar protein yang berbeda pada sistem bioflok ikan Gurami dengan kadar protein yang lebih tinggi.

\section{DAFTAR PUSTAKA}

Afifi IM. 2014. Pemanfaatan Bioflok pada Budidaya Ikan Lele Dumbo (Clarias Sp.) dengan Padat Tebar Berbeda terhadap Laju Pertumbuhan dan Survival Rate (SR) [Skripsi]. Surabaya : FPIK UNAIR.

Aji SB, Sudaryono A, Harwanto D. 2014. Pengaruh Penambahan Sumber 
Karbon Organik Berbeda terhadap Pertumbuhan dan Rasio Konversi Pakan Benih Lele "(Clarias Sp.)" dalam Media Bioflok. Journal of Aquaculture Management and Technology 3(4): 199-206.

Apriani I. 2015. Produksi Benih Ikan Patin (Pangasianodon Hypophthalmus) dengan Penambahan Sumber Karbon Berbeda pada Sistem Budidaya Berbasis Bioflok [Thesis]. Bogor: Sekolah Pascasarjana, Institut Pertanian Bogor.

Avnimelech Y. 1999. Carbon/Nitrogen Ratio as a Control Element in Aquaculture Systems. Aquaculture: 227-235.

Azhar MH. 2013. Peranan Sumber Karbon Eksternal yang Berbeda dalam Pembentukan Bioflok dan Pengaruhnya terhadap Kualitas Air serta Produksi pada Sistem Budidaya Udang Vaname Litopenaeus Vannamei [Thesis]. Bogor: Sekolah Pascasarjana, Institut Pertanian Bogor.

Boyd CE. 1979. Water Quality Management in Warm Water Fish Pond. Alabama: Master Printer, Inc.

Crab R, Defoirdt T, Bossier P, Verstraete W. 2012. Biofloc Technology in Aquaculture: Beneficial Effects and Future Challenges. Aquaculture: 351 $-356$.

Diatin I. 2016. Intensifikasi Budidaya Ikan Hias Koridoras (Corydoras aeneus) [Thesis]. Bogor: Sekolah Pascasarjana, Institut Pertanian Bogor.

Effendie MI. 1997. Biologi Perikanan. Yogyakarta: Yayasan Pustaka Nusatama.
Ekasari J. 2009. Teknologi Bioflok: Teori dan Aplikasi dalam Perikanan Budidaya Sistem Intensif. Jurnal Akuakultur Indonesia 8(2): 117-126

Emerenciano M, Gaxiola G, Cuzon G. 2013. Biofloc Technology (BFT): A Review for Aquaculture Application and Animal Food Industry. Mexico : Unidad Multidisciplinaria de Docencia e Investigación (UMDI).

Farzanfar A. 2006. The Use of Probiotics in Shrimp Aquaculture. FEMS Immunology and Medical Microbiology 48(2): 149-158.

Hargreaves JA. 2013. Biofloc Production Systems for Aquaculture. Southern Regional Aquaculture Center 4503.

Kusuma AP, Istirokhatun $\mathrm{T}$, Purwono. 2017. Pengaruh Penambahan Urin Sapi dan Molase Terhadap Kandungan C Organik dan Nitrogen Total Dalam Pengolahan Limbah Padat Isi Rumen RPH dengan Pengomposan Aerobik. Jurnal Teknik Lingkungan 6(1) : $1-9$.

Lisah. 2004. Pengaruh Beberapa Tingkat Pemberian Pakan Buatan Terhadap Pertumbuhan dan Sintasan Benih Ikan Gurami (Osphronemus gouramy Lac) [Skripsi]. Bogor: Fakultas Pertanian, Universitas Djuanda Bogor.

Manurung UN, Susantie D. 2017. Identifikasi Bakteri Patogen pada Ikan Nila (Oreochromis niloticus) di Lokasi Budidaya Ikan Air Tawar Kabupaten Kepulauan Sangihe. Budidaya Perairan 5(3) : 11 - 17.

Muarif. 2016. Karakteristik Suhu Perairan di Kolam Budidaya Perikanan. Jurnal Mina Sains 2 (2) : 96 - 101.

National Research Council (NRC) 1997. Nutrient Requirement of Warm Water 
Fishesand Shellfish. Washington: National Academy Press.

Ohoiulun AH. 2003. Pengaruh Padat Penebaran terhadap Kualitas Air pada Pendederan Benih Gurame (Osphronemus gouramy Lac) Sistem Resirkulasi [Skripsi]. Bogor: Fakultas Pertanian, Institut Pertanian Bogor.

Putri SA. 2014. Pemanfaatan Bakteri Heterotrof terhadap SR (survival rate) dan Laju Pertumbuhan Ikan Lele Dumbo (clarias sp.) dengan Sistem Tanpa Pergantian Air [Skripsi]. Surabaya: Fakultas Perikanan dan Kelauatan, Universitas Airlangga.

Rosmawati, Muarif. 2017. Growth and Feed Efficiency of Gourami Fish Reared in Biofloc Media with Different $\mathrm{C} / \mathrm{N}$ Ratios. International Journal of Sciences Basic and Appiled Research (IJSBAR) 36(6) : $47-59$.

Schryver PD, Crab R, Defoirdt T, Boon N, Verstraete W. 2008. The basics of bio-flocs technology: The added value for aquaculture. Aquaculture : 125-137.

Steel RGD, Torrie JH. 1985. Principles and Procedures of Statistic, Biometrical Approach. Kogakushi: Mc Graw Hill.

Sutarmat T. 2006. Studi Pendahuluan Pemeliharaan Ikan Merah dalan KJA dengan Ukuran tebar yang Berbeda. Prosiding Konferensi Akuakultur Indonesia 193 - 197.

Sulhi M. 2007. Produksi Benih Ikan Gurame Di lahan Sempit. Seminar Nasional Hari Pangan Sedunia 174 179.

Sulistyo J, Muarif, Mumpuni FS. 2016. Pertumbuhan dan Kelangsungan
Hidup Benih Ikan Gurami (Osphronemus Gouramy) pada Sistem Resirkulasi dengan Padat Tebar 5,7 dan 9 Ekor/Liter. Jurnal Pertanian 7 (2) : 87 - 93.

Usman, Palinggi NN, Harris E, Jusadi D, Supriyono E, Yuhana M. 2010. Analisis Tingkat Kecernaan Pakan dan Limbah Nitrogen (N) Budidaya Ikan Bandeng Serta Kebutuhan Penambahan C-Organik untuk Penumbuhan Bakteri Heterotrof. Jurnal Riset Akuakultur 5(3) : 481 490.

Usman, Haris E, Jusadi D, Supriyono E, Yuhana M. 2011. Penumbuhan Bioflok Dalam Media Budidaya Ikan Bandeng. Jurnal Riset Akuakultur 6(1): $41-50$.

Zakaria R. 2008. Kemunduran Mutu Ikan Gurami (Osphronemus gouramy) Pasca Panen pada Penyimpanan Suhu Chilling [Skripsi]. Bogor: Fakultas Perikanan dan Ilmu Kelautan, Institut Pertanian Bogor.

Zonneveld NEA, Huisman, Boon JH. 1991. Prinsip-prinsip budidaya ikan. Jakarta: Gramedia pustaka utama. 